\title{
「小児肺炎診癔カイドライン」に関する基礎的検討
}

\section{5．ウイルス性肺炎の診断 ウイルス検査}

\author{
鈴木 宏 \\ (新潟大学大学院医歯学総合研究科国際感染医学講座)
}

\begin{abstract}
要旨：急性呼吸器疾患（ARI）は多種類のウイルスが原因であり，検査室診断は必要となる。ウイ ルス分離や血清抗体検査が行われても, 結果が出るまでには時間がかかった。しかし，インフルエ ンザウイルス感染への簡便な迅速診断の導入と抗ウイルス剤の登場により, 臨床の第一線の環境が 大きく変化した。更には, PCR 法による抗原検索も高頻度で行われるようになった。

ウイルス学的検索に際し, 臨床症状, 年齢, 季節性, 周囲での流行状況などから病因ウイルスを 推測して検索する事は大切である。また，不明な ARIにおいては検体を積極的に採取し，県や国の 検査機関に送ることも重要である。
\end{abstract}

Abstract: Acute respiratory infections (ARI) are the most common afflictions of humans, and mostly are caused by viruses. A definitive diagnosiis of virus infections requires laboratory confirmation. Viral isolation and serological diagnosis are carried out, but several days require for receiving those final results. However, introduction of rapid diagnosis and effective antiviral drugs for influenza completely changed those conditions at the first line of clinics. Furthermore, PCR-based assay as viral detection methods was used frequently.

On the laboratry diagnosis, causative agents should be presumed on the basis of clinical manifestation, age, seasonality, and epidemiologica information arrounding sites. The clinical samples from unknown ARI cases also schould be collected actively and sent to prefectural or national laboratories for further research. (JJPP $2003: 14: 194-197$ )

Key word：ウイルス, 急性呼吸器疾患

\section{1.はじめに}

急性呼吸器疾患 (ARI) の臨床症状は, 発熱, 頭痛以外に咳, 鼻汁, 鼻閉, 咽頭痛などと非特 異的でしかも多種類のウイルスが病因であるこ とより，臨床症状だけからの鑑別は不可能であ る1)。しかし，ウイルス性 ARI の病原診断とし て, ウイルス分離や血清抗体検査で行われても, 結果が出るまでには時間がかかり治療とは直接 結びつかなかった。このような状況が，インフ ルエンザウイルス感染への簡便な迅速診断の開 発・導入に加え抗ウイルス剤の登場，更には PCR 法による抗原検索も高頻度で行われるな ど大きく変化してきた。

\section{2. 対象ウイルス}

歴史的には「かぜ」の病原ウイルス発見とし て，1933年にインフルエンザウイルスが発見さ れて以降，1950，60年代には現在報告されてい るウイルス性 ARI の大多数のウイルスが分離 された (表 1 ) 4)。しかし，2001年になり新たに パラミキソウイルスに分類されるメタニュウモ ウイルスが，RSと同様な喘鳴を主訴とする患 者から検出された 3 , 4,5)。本ウイルスは乳幼児期 に主に罹患し，RSウイルスと重感染すると重 症化するとされる7)。更には，コロナウイルス は1965年に分離され，普通感冒 (common cold) の病因となるが1,2)，これとは全く異なる新型ウ 
イルスとして, 平成15年 2 月から発生した重症 急性呼吸器症候群 (severe acute respiratory syndrome, SARS）の病原である SARSコロナ ウイルスが登場した3)。なお，他には，高い頻 度で見られるのがライノウイルスで「はなかぜ」 の病因で 100 種以上あり，次いでパラインフル エンザウイルスである。なお，アデノウイルス は咽頭炎，咽頭結膜熱 (プール熱)，RSウイル スは乳幼児の急性細気管支炎の病因となり，イ ンフルエンザウイルスは全体の 5-15\%である (表 2 )。

\section{3. 対象患者}

臨床症状は，発熱，頭痛以外に咳，鼻汁，鼻 閉, 咽頭痛等の呼吸器症状を呈する患者が対象 である。特にインフルエンザ様疾患 (influenzalike illness, ILI）の診断基準として, 37.8（又 は38.0) ${ }^{\circ} \mathrm{C}$ 以上の発熱に加えて, 咳嗽, 咽頭痛, 鼻汁の一つの症状を有する人をインフルエンザ ワクチン効果判定に用いている7)。

\section{4. 検査材料}

検査材料は, 発症早期の咽頭拭い液, 鼻腔拭 い液, 鼻咽頭吸引液あるいは洗浄液, $\mathrm{BAL}$ （気管支洗浄液）などがある。RSウイルス，イ ンフルエンザウイルスなどでは咽頭拭い液より 鼻咽吸引液が分離率や抗原診断検査陽性率が高 いとされている。検査までの保存は短期的には $4{ }^{\circ} \mathrm{C}$ 保存が最適で, 特にRSウイルスにおいて は凍結は避けるべきである。しかし，長期に保 存する際はー $80^{\circ} \mathrm{C} て ゙$ 行う。

\section{5. 検査診断法}

診断法として, 血清診断, ウイルス分離, 抗 原検査，PCR 法等があるが，ゴールデンスタ ンダードでしかもウイルス性状を知るためにも 分離は重要である。これらの検査法を駆使して も, 診断可能なのは全体の $20-30 \%$ に止まるが, これは検体採取法, 輸送法, 検査法などが原因 としてあげられる。季節によってウイルス性

表 1 「かぜ」の病原ウイルスの発見推移 ${ }^{2)}$

\begin{tabular}{ll}
\hline 発見年 & \multicolumn{1}{c}{ ウイルス } \\
\hline 1933 年 & インフルエンザウイルス \\
1953 & アデノウイルス \\
1956 & パラインフルエンザウイルス、ライノウイルス、R S ウイルス \\
1958 & エンテロウイルス \\
1965 & コロナウイルス \\
2001 & メタニュウモウイルス \\
2003 & SARSコロナウイルス \\
\hline
\end{tabular}

表 2 「かぜ」の病原ウイルスの種々の特性（2）を改変）

\begin{tabular}{|c|c|c|c|c|c|}
\hline \multirow[t]{2}{*}{ ウイルス } & \multirow[t]{2}{*}{ 年間の検出頻度 } & \multicolumn{4}{|c|}{ 季節変動 } \\
\hline & & 冬 & 春 & 夏 & 秋 \\
\hline ライノウイルス & $30-50 \%$ & + & & & + \\
\hline コロナウイルス & $10-15$ & + & & & \\
\hline インフルエンザウイルス & 5-15 & + & & & \\
\hline RSウイルス & 5 & + & & & \\
\hline パラインフルエンザウイルス & 5 & & & & $+(1,2$ 型 $)$ \\
\hline アデノウイルス & $<5$ & & + & & \\
\hline エンテロウイルス & $<5$ & & & + & \\
\hline メタニュウモウイルス & 不明 & $?$ & & & \\
\hline 不明 & $20-30$ & & & & \\
\hline
\end{tabular}


ARI の病原ウイルスは異なり（表 1)，この情 報は診断法を選別する際に重要となる。

\section{1 ）血清診断（抗体検査）}

検査法とし, 中和抗体法 (NT), 補体結合反 応 $(\mathrm{CF})$, 蛍光抗体法 $(\mathrm{FA})$, 酵素抗体法 (ELISA)，ラジオイムノアッセイ（RIA）等が ある。診断には急性期と回復期のペア血清を用 い，4 倍以上の抗体の有意上昇を確認するが， 最終診断に時間を要することより，参考意見に 留まることが多い。初感染では IgM 抗体を検 出を行い, 検査法とし FA 法が簡便であるが, ELISA 法や RIA 法はより感度が高い。

抗体検索は病原ウイルスの特定を補佐する手 法であり，むやみにスクリーニングとして多数 のウイルス検査することは避けるべき事と思わ れる。

検査結果の解釈時の注意点として, ワクチン 接種歴, 抗原の変異等も結果の評価には考慮す る必要がある。また，既存抗体によるいわゆる 抗体価の「頭打ち」現象から，抗体価上昇が有 意に上昇するにいたらず，感染したと判定され ない例がある点を留意すべきである。

\section{2 ）ウイルス分離}

多種類の ARI 関連ウイルスを分離するには, まづウイルスに最適な培養細胞の選択が必要で ある。この対処法として, 沼崎らは $\operatorname{HEF}$ (ヒト 胎児由来細胞), Hep-2 (ヒト喉頭ガン由来), Vero(サル腎由来), MDCK (犬腎由来), HMVII (ヒトメラノーマ細胞由来) の 5 種類の細胞 を組み合わせたマイクロプレート法を開発し多 くの成果を得ている ${ }^{8,9)}$ 。この方法の利点として, 細胞変成 (CPE) を示した細胞の種類により, 同定に要する時間を短縮できることである（表 3 )。例えば，MDCK にCPEを示せば，イン フルエンザウイルの可能性があり，次のステッ プである血清型の分類に進める。また，エンテ ロウイルスには多くが含まれるが, HEF, HEp-2, Vero 細胞の 3 種に同時に CPE がくれ ば，ポリオウイルスの可能性が強く，これでも 次の血清型の分類に進めるなどである。

\section{3) 抗原診断法}

検査法とし蛍光抗体法 (FA), 酵素抗体法 (ELISA)，ラジオイムノアッセイ（RIA）等が ある。ウイルス性肺炎の診断法として, 今後迅

表 3 複数細胞を用いた急性呼吸器疾患の病原ウイルス検出

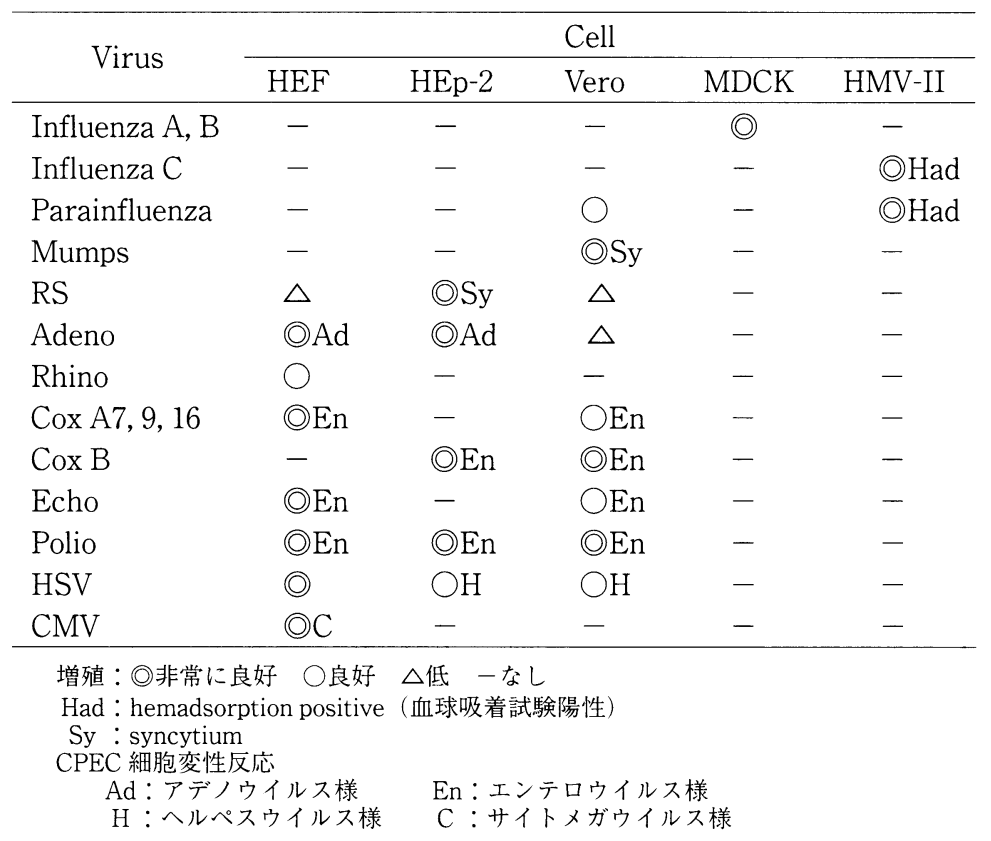


速診断の開発は進むと思われる。しかし，目的 とするウイルスの選択には, 常にウイルスの特 性である病因ウイルス別の罹患年齢や季節によ つて頻度が異なる特徴に留意すべきである。そ の際に，サーベイランス情報は参考となる。

迅速分離診断法として, シェルバイアル法と して細胞に接種する際に遠心法を加え, 感染 $1-2$ 日後に蛍光抗体法を用いて種々のウイル 又診断も可能である10)。

市販の迅速診断法がインフルエンザウイル ス，RSウイルス，アデノウイルス等で行われ ている。特にインフルエンザウイルスでは処理 過程が単純な迅速診断キットが主流である。感 度や特異性で問題が残るが, 短時間で, どのレ ベルの施設でも手軽に用いられる特徵より，臨 床現場では今後ますます重用されると思われる。

\section{4 ) 分子生物学的手法 (ウイルス核酸検出法)}

PCR 法による診断は殆どのウイルスに対し て短時間に可能であることから，今後はこの方 法による仕事が増加すると思われる。PCR 産 物からの genotype（遺伝子型）の決定と, 各 型の関連をシークエンスを行って樹形図を作成 してのウイルス伝播形式の検討もおこなう分子 疫学が主流をなしている。PCR 産物からの制 限酵素切断パターン解析も同様に用いられてい る。しかし，この PCR による検査にあたって は常に污染物の混入による擬陽性を念頭に入 れ，実験操作は慎重に行う必要がある。

インフルエンザにおいては抗ウイルス剤が使 用されているが，耐性株の出現が問題となって いる11,12)。この診断には分離ウイルスからでも 行われるが，PCRによる特定の塩基の変異に よる診断も可能である。

\section{6.おわりに}

ウイルス性 ARI，肺炎診断にはウイルス学 的検索は不可欠ではあるが， ウイルスによって は迅速診断が導入され，どのレベルの医療機関 でも診断が行われるようになってきた。この際 には, 臨床症状, 年齢, 季節性, 周囲での流行
状況などから病因ウイルスを推測して検索を勧 める事が大切である。更には，今回の SARS 騒 ぎでも有効に機能した例があるが，不明な ARI においては，咽頭拭い液や鼻咽頭吸引液あるい は洗浄液, ペア血清などを採取・保存し, 県や 国の検査機関に送ることは極めて重要である。

\section{参考文献}

1）鈴木 宏. かぜ病原ウイルスの現状. 今日の 治療. 4:88-96, 1996.

2 ) Heikkinen T, Jarvinen, T. The common cold. Lancet 361: 5159, 2003.

3 ) van den Hoogen BG, de Jong JC, Groen J, et al. A newly discovered human pneumovirus isolated from young children with respiratory tract disease. Nat Med. Jun; 7(6): 719-24, 2001.

4) Greensill J, McNamara PS, Dove W, et al. Human metapneumovirus in severe respiratory syncytial virus bronchiolitis. Emerg Infect Dis. 9: 372-5, 2003.

5 ）鈴木 陽，渡邊王志，西村秀一。喘鳴をきた した小児からのhuman metapneumovirus の 検出. 感染症誌77：467-468, 2003.

6 ) CDC. Update:outbreak of severe respiratory syndrome-worldwide, 2003. MMWR; 52: 241248, 2003

7 ) Nicholson KG (editor). Managing influenza in primary care. Blackwell Science UK. 1999.

8 ) Numazaki, Y, Oshimat, Ohmi A et al. A microplate method for isolation of viruses from infants and children with acute respiratory infections. Microbio Immunol. 31: 1085-1095, 1978.

9 ) 沼崎義夫. ウイルス分離の簡便法. 小児科臨 床, 54：127-132, 1991.

10) Eagler HD, Selepak ST. Effect of centrifuging shell vials at $3,500 \mathrm{xg}$ on detection of viruses in clinical specimens. J Clin Microbiol. 32: 1580-1582, 1994.

11) Saito,R, Oshitani, H, Masuda, H, Suzuki, H. Detection of amantadine-resistant influenza A strains in nursing homes by PCRrestriction fragment length polymorphism analysis with nasopharyngeal swabs. J. Clin. Microbiol. 40: 84-88, 2002.

12) H.Suzuki, R.Saito, H.Oshitani. Excess amantadine use and resistant viruses. Lancet 358: 1910, 2001. 